\title{
Energy resource structure and on-going sustainable development policy in Nigeria: a review
}

\author{
Fidelis I. Abam • Bethrand N. Nwankwojike • \\ Olayinka S. Ohunakin $\cdot$ Sunday A. Ojomu
}

Received: 24 November 2013/Accepted: 8 April 2014/Published online: 25 April 2014

(C) The Author(s) 2014. This article is published with open access at Springerlink.com

\begin{abstract}
Nigeria is rich in both conventional and renewable energy resources that empower the country with a large capacity to develop an effective national energy policy. The study aims at reviewing the current energy resource structure of Nigeria in terms of production and utilization, comparing sectoral performance and reviewing issues confronting energy growth, sustainability, policies and frameworks towards the actualization of energy efficiency. The total energy consumption in 2011 was 28.8 million tons of oil equivalent about $5.4 \%$ of the world value in 2010. Nigeria share of world $\mathrm{CO}_{2}$ emissions in 2011 was $0.32 \%$ and a drop of $0.02 \%$ in 2010. In addressing the country's challenges of energy demand, production, consumption and related environmental problems, the government has initiated sustainable and effective energy conservation strategies to improve efficiency. These include: reduction of energy consumption at the household sector, reduction of gas flaring, adoption and maximum renewable energy technologies, reduction of energy intensity in industries by appropriate energy conservation and management system. In addition, the policies also include the development and integration of alternative energy resources such as nuclear, biomass, wind and solar
\end{abstract}

F. I. Abam $(\bowtie) \cdot$ B. N. Nwankwojike

Department of Mechanical Engineering, Michael Okpara

University of Agriculture, Umudike,

Umuhia P.M.B 7267, Abia State, Nigeria

e-mail: abamo124@gmail.com

O. S. Ohunakin

Department of Mechanical Engineering, Covenant University, Ota P.M.B 1023, Ogun State, Nigeria

\section{S. A. Ojomu}

Department of Electrical/Electronics Engineering, Cross River University of Technology, Calabar P.M.B 1123, Nigeria into the total energy mix structure. For all these to be accomplished, the energy development strategy must follow a sustainable framework to balance economic growth, social expansion and eco-friendly protection.

Keywords Energy · Sustainable development · Energy policy $\cdot$ Environmental impacts $\cdot$ Nigeria

\section{Introduction}

Energy remains the principal driving force for both economic and industrial developments of all nations of the world. It is the midpoint of economic, environmental and developmental issues confronting the world at the moment. Clean, efficient, stable and sustainable energy services are, therefore, ideal for global prosperity. Developing economies like Nigeria require a robust access to reliable and advanced energy services due to the escalating population and socioeconomic activities; this will bring about the reduction in poverty level, improve health conditions, enhance productivity, maintain competitiveness and promote economic growth in all ramifications [1,2].

The economy of Nigeria became dependent on oil from the 1970s till date; it has contributed over $98 \%$ of export earnings and $85 \%$ of government revenue. However, this over dependence of the economy on oil has caused it to be highly responsive to external influences [3]. Consequently, the high proceeds obtained from crude oil export in all these years brought about an unsustainable spending profile, which led to economic catastrophe when global petroleum prices crashed in $1986[4,5]$. This induced huge dislocation in the economy, joined with gross mismanagement of resources and resulted into borrowing leading to increase in external debt. Since a large amount of proceeds earned from oil were 
not properly utilized for meaningful and sustainable development, poverty continued to be in the rise and people remain deprived of efficient energy services and sustainable livelihoods. The levels of energy consumption in Nigeria are currently identified to be low with about $701 \mathrm{~kg}$ of oil equivalent per capita and electricity consumption of 134 $\mathrm{kWh}$ per capita [6]. The average gross domestic product (GDP) growth rate from 2005 to 2012 was $6.9 \%$ reaching a height of $8.6 \%$ in December 2010 and a low value of $4.5 \%$ in March 2009. The GDP in 2011 corresponds to $0.38 \%$ of the world economy and comparable to $\$ 235.95$ billion [7]. The economy is projected to grow at $7.43 \%$ in 2014 and $7.25 \%$ in $2015[8,9]$. Crude oil (the mainstay of the economy) and electricity power generation and consumption are thus faced with numerous difficulties including: (1) youth restiveness/militancy in the oil exploration regions, (2) high level of gas flaring, (3) low electricity generation, (4) low and decaying transmission infrastructures, (5) poor energy efficiency practices, (6) poor energy management systems and (7) high environmental degradation and emissions [10].

The IMF ranking in 2010, places Nigeria on 31st position by GDP on purchasing power parity basis in the world's economies of countries. This ranking led to the government's frantic effort to place the country among the first 20 economies of the world by 2020 through the development of a blueprint tagged 'Vision 20:2020' (Federal Government's postulation for industrialization). This calls for the country to grow her economy from the present growth rate of about $6-13.8 \%$ per annum leading to a per capita income of about 4,000 USD. In achieving the Vision 20:2020, one input that is very vital towards the realization is energy. Hence, there will be the need to ensure energy optimization in all sectors of the economy, improve environmental and social security and tackle issues of poor energy efficiency attitudes through proper energy management system to meet with the needs for sustainable growth.

In view of this, there is need to provide adequate information that is vital for the realization of Vision 20:2020 in a bid to have an industrialized nation. The objective of this paper is thus to review (1) the current energy resource structure of Nigeria in terms of production and utilization, (2) the performance of energy sectors based on some economic indicators and (3) issues confronting energy growth, expansion strategy and sustainability alongside with policies and frameworks needed for the actualization of energy efficiency and conservation.

\section{The current energy resource structure of Nigeria}

Nigeria is endowed with enormous energy resources which put her in a position to bring about change to her economy and better the lives of her citizens. Energy demand in Nigeria has been in the increase in the last three decades; energy consumption in 2011 increased by $3.6 \%$ over that in 2010 giving a total energy utilization value of 4.4 Quadrillion Btu [115,000 million tons of oil equivalent (m toe)], of which conventional biomass and waste contributed about $82 \%$ of the overall energy consumption [11-13]. The high share of biomass energy in the overall energy consumption reflected the adoption of biomass in meeting off-grid heating and cooking requirements, primarily in the rural areas. The electrification rates for the entire country in 2011 was $45 \%$ leaving almost 79 million people without electricity [11]. In addition, the entire energy supply in the country is over $80 \%$ domestic with oil dominating the primary energy mix. This, however, led the government to the process of restructuring the energy sector and will cover the whole chain, starting from oil exploration and exploitation (up- and downstream sectors), power generation, transmission and distribution. Various energy resources in vast deposit in the country are thus discussed:

\section{Natural energy resources}

Nigeria has varied energy resources and primarily rich in crude oil and natural gas which placed her on the tenth and ninths positions, respectively, of the global world reserves in 2011 [9]. In spite of holding the largest natural gas reserves in Africa, the country lacks adequate infrastructure needed for the optimal development of the sector. Hence, natural gas related with oil production is usually flared thereby resulting to increase in environmental degradation. However, with the on-going development of regional gas pipelines, extension of the liquefied natural gas (LNG) infrastructure, and policies to stop gas flaring, development for export and domestic utilization in the sector are anticipated to accelerate [3,9]. The geographical spreads of fossil deposits concentrate more in the south-south and southeast geo-political regions of the country. Energy transportation (particularly for refined petroleum products) throughout the remaining geo-political zones of the country poses a heavy burden on the Nigerian National Petroleum Corporation (NNPC) and the Independent Petroleum Marketers Association of Nigeria (IPMAN), leading to uneven product costs across the country due to varying transportation logistics and costs.

Fossil fuel-based energy resources

\section{Coal}

The estimated coal reserve in the country is about 2.7 billion tons in 2011, out of which 650 million tons are 
Table 1 Some coal mining sites in Nigeria [16, 17]

\begin{tabular}{lllcr}
\hline Sites & Coal type & $\begin{array}{l}\text { Estimated } \\
\text { reserves (Mt) }\end{array}$ & $\begin{array}{l}\text { Proven } \\
\text { reserves } \\
(\mathrm{Mt})\end{array}$ & $\begin{array}{r}\text { Depth of } \\
\text { coal (m) }\end{array}$ \\
\hline Oyeama & Sub-bituminous & 150 & 40 & 180 \\
Ogboyoga & Sub-bituminous & 427 & 107 & $20-100$ \\
Ogwashi & Lignite & 250 & 63 & $15-100$ \\
Ezimo & Sub-bituminous & 156 & 56 & $30-40$ \\
Owukpa & Sub-bituminous & 75 & 57 & $20-100$ \\
Okaba & Sub-bituminous & 250 & 73 & $20-100$ \\
Okpara & Sub-bituminous & 100 & 24 & 180 \\
\hline
\end{tabular}

roughly proven (about $0.02 \%$ of the world total proven). The production capacity declined from 0.91 million tons in 1959 , to an insignificant level in 2011. The drop in production capacity was due to reduction in coal demand and its replacement with gas and diesel as fuel sources to thermal power generation $[11,14,15]$. Nigeria ranked low in world coal production by contributing $0.0001 \%$ of the world share [11]. Coal distribution in the country is uneven across the regions, extending from the cretaceous Anambra basin (southeast) to Dekina (north-central) the Benue basin. Mine production capacity after full rehabilitation and privatization at principal mining sites in Nigeria may possibly obtain the following levels: Onyeama and Okpara (150,000-400,000 tons/year), Owukpa (2,500 tons/year) and Okaba $(15,000-300,000$ tons/year) $[15,16]$. Some of these mine sites are presented in Table $1[16,17]$.

\section{Crude oil}

The estimated oil reserves stood at 37.2 billion barrels in 2011 accounting for approximately $2.3 \%$ of the total global reserves (Fig. 1) [11]. The average crude oil production in 2011 was about 2.13 million barrels per day (mbpd) compared to the $2.05 \mathrm{mbpd}$ in 2010 [12]. In 2011, Nigeria was the twelfth highest producer of crude oil in the world with $2.9 \%$ of the world total share (Fig. 2). Furthermore, the federal government anticipates increasing proven oil reserves to 40 billion barrels in the years ahead. Though, the rate of exploration is at their lowest as only three exploratory wells were drilled in 2011, compared to over 20 wells drilled in 2005. In addition, the average crude oil production in 2012 was over $2.15 \mathrm{mbpd}$. The increase in production was due to the extension of the existing fields and recent production from deep water fields. The latest deep water field to come on board as at 2012 was Total's Usan field, which began production of over 100,000 barrels per day (bpd) in July 2012 and was expected to reach 180,000 bpd by the end of 2012 [7, 13].

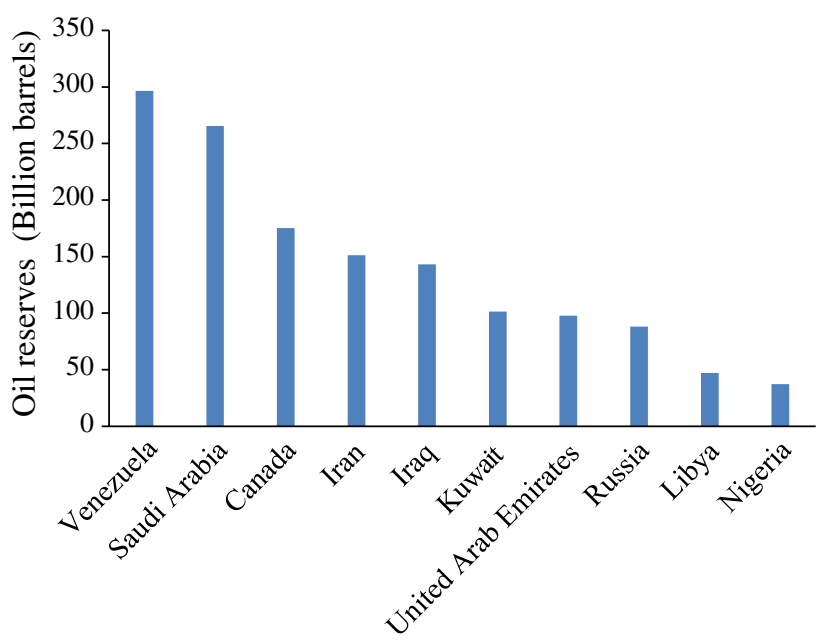

Fig. 1 Proven world oil reserves for 2011 (Billion barrels). Data source [11]

\section{Natural gas}

Nigeria has estimated proven reserves of about 5.1 trillion cubic meters $(\mathrm{tcm})$ of natural gas $(\mathrm{NG})$ which approximates $2.5 \%$ of the world total in 2011 and placing the country as the ninth leading NG reserve holders in the world and the biggest in Africa. The production capacity in 2011 was about 39.9 billion cubic meters (about $1.2 \%$ of the world share), which gave Nigeria the 16th position in world's NG production [13]. The distribution of NG in Nigeria is uneven across the regions. Most of the NG reserves are located in the Niger Delta region of the country. A significant portion of the country's marketed natural gas is processed as LNG. In 2010, about 17.97 million metric tons ( $875 \mathrm{bcf}$ ) of LNG was exported, making Nigeria the fifth largest LNG producer in the world [13]. The level of natural gas utilization in the country remains low since a large quantity of the produced associated gas is flared due to inadequate infrastructure and market outlets. There is the need to develop a large gas market and adequate infrastructures to improve the sector so as to reduce revenue loss due to gas flaring.

\section{Nuclear power}

Nigeria's nuclear strategy started shortly after her independence in 1960. The government is on the path of positioning Nigeria on nuclear development [18]. In Africa, South Africa is the only country that has utilized the energy gotten from nuclear deposits with capacity of about 12.7 terawatt-hours for the year 2011 accounting for $0.5 \%$ of the world's total consumption share. Considering the nation's electricity supply, nuclear power will undoubtedly help improve the energy problems. More 
Fig. 2 World percentage share of crude oil production in 2011. Data source [11]

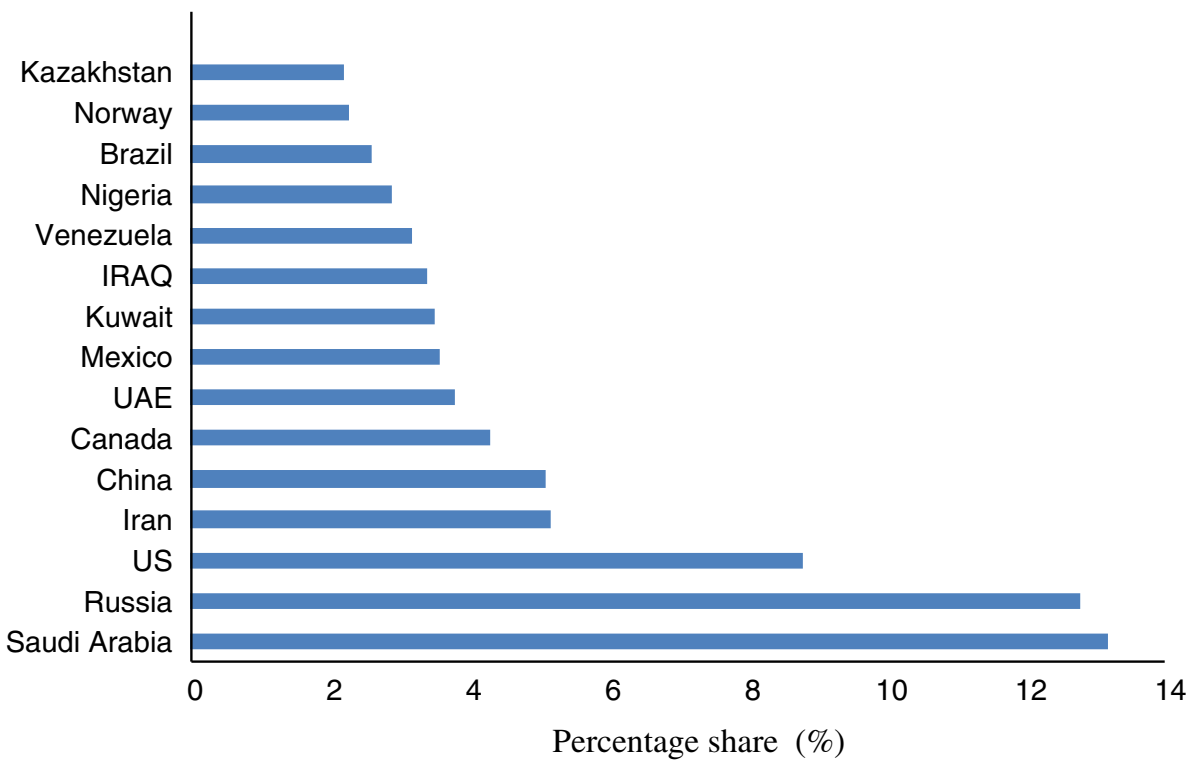

importantly, nuclear development has benefits that go beyond electricity supply. Its application in agriculture, health, science and technology cannot be overemphasized. Nuclear development is further captured in Nigerian energy master plan.

\section{Renewable energy resource base}

Nigeria is endowed with abundant deposit of renewable energy (RE) potentials ranging from solar, wind, hydro (small and large), biomass and fuel wood; RE has placed Nigeria in a better position to advance her internal energy strategies. However, the country is yet to integrate the vast RE potential into the energy mix. In addition, the mainstream energy supply chain is at present dependent on fossil fuels and firewood. These sources are grossly depleted due to the inability to harness other energy resources. The RE capacity is thus discussed in the following subsections.

\section{Hydropower energy resources}

The current hydropower potential of Nigeria accounts for about $30 \%$ of the total electricity power supply [3]; this value is relatively insignificant when compared to the world hydropower energy production. The three main hydropower plants in Nigeria are located in Kainji, Jebba and Shiroro with installed capacities of 800, 578 and $600 \mathrm{MW}$, respectively, to bring the total installed large hydro capacity to $1,978 \mathrm{MW}$. The overall exploitable hydropower potential at 2011 was about 14,750 MW of which $3,500 \mathrm{MW}$ is from the small hydropower plants, and 11,259 MW from the large ones [3]. The exploitable rate at the end of 2011 was about $13.41 \%$. This rate is low when compared to countries like Norway, Japan, Sweden, France and China with developed proportion of their hydropower potentials standing at about 45, 61, 69, 68 and $30 \%$ in 2009, respectively, and installed capacities of $27.53,27.23,16.21,25.34$ and $196.79 \mathrm{GW}$ in that order [19-21].

The percentage electricity generation in the country was $25 \%$ hydro, $12 \%$ thermal (oil) and $63 \%$ thermal (gas) in 2011 [19]. The statistics shows that the larger portion of electricity generated was from thermal power plants with about two-thirds of thermal power derived from natural gas. Hydropower used to contribute the larger portion of the total energy mix, but in recent years, all the hydro lakes have been the victim of climate change leading to the subsequent reduction of water intake into the power dams. Because of the fall in the contribution of hydro to the energy mix, the federal government in 2009 proposed the construction of additional hydropower stations as listed in Table 2.

\section{Wind energy resources}

It is a form of clean energy that has been experiencing rapid growth in recent decades due to the promotion of models of renewable energy sources, energy supply security, fuel diversity concerns, ecological awareness, and economic reasons [22]. Due to its many advantages, wind energy has also become the fastest growing renewable source of energy in both developed and developing countries [23]. Nigeria was found to be a poor/moderate wind regime with wind speeds ranging from 2.12 to $4.13 \mathrm{~m} / \mathrm{s}$ in the southern part of the country with the exception of the 
Table 2 List of proposed hydropower stations and year of completion $[9,19]$

\begin{tabular}{|c|c|c|c|c|}
\hline $\begin{array}{l}\text { Hydropower } \\
\text { station }\end{array}$ & Type & $\begin{array}{l}\text { Capacity } \\
\text { (MW) }\end{array}$ & $\begin{array}{l}\text { Name of } \\
\text { reservoir }\end{array}$ & River \\
\hline $\begin{array}{l}\text { Zungeru power } \\
\text { station }\end{array}$ & Reservoir & 700 & & $\begin{array}{r}\text { Hadeja } \\
\text { River }\end{array}$ \\
\hline $\begin{array}{l}\text { Kano power } \\
\text { station }\end{array}$ & Reservoir & 100 & N/A & $\begin{array}{r}\text { Hadeja } \\
\text { River }\end{array}$ \\
\hline $\begin{array}{l}\text { Zamfara power } \\
\text { station }\end{array}$ & Reservoir & 100 & $\begin{array}{l}\text { Gotowa } \\
\text { lake }\end{array}$ & $\begin{array}{c}\text { Bunsuru } \\
\text { River }\end{array}$ \\
\hline Kiri power station & Reservoir & 35 & N/A & Benue River \\
\hline $\begin{array}{l}\text { Mambilla power } \\
\text { station }\end{array}$ & Reservoir & 3,050 & N/A & Donga River \\
\hline
\end{tabular}

coastal regions/offshore, and the north having speeds ranging from 4.0 to $8.60 \mathrm{~m} / \mathrm{s}$ [24-28]. The total actual exploitable wind energy reserves range from 8 to $97 \mathrm{MWh} /$ year in the north and the northeast region of the country [29]. The level of wind power development is still low in the country with the few available wind field limited to the 5 and the $0.7 \mathrm{kWp}$ located in the Sayya Gidam and Danjawa, respectively, in the north. A pilot project on the generation of large-scale grid-connected power using wind energy commenced at Katsina State in 2007 with a capacity generation of $10 \mathrm{MW}$.

\section{Biomass energy resources}

Biomass resources of abundance in Nigeria include dead trees, wood chips, tree trumps, animal and human waste, household and organic waste from industries. It is the primary source of energy in Nigeria constituting about $37 \%$ of overall energy consumption among the rural settlers and semi-urban dwellers [20, 29]. The total crop residues and animal waste produced is 83 and 61 million tons/year, respectively, while about 80 million cubic meters $\left(43.4 \times 10^{9} \mathrm{~kg}\right)$ of fuel wood is consumed yearly, with average daily consumption varying from 0.5 to $1.0 \mathrm{~kg}$ of dry wood per capita [3,29]. Wood fuel is used mainly for cooking, heating and other domestic purposes. Biomass resources estimate in Nigeria as at 2011 was above $816 \mathrm{MJ}$ (0.02 tons of oil equivalent) [28, 30]. Biomass is still used mostly in its crude form in the country, though future utilization as a sustainable energy solution through biodiesel production is in view by the government [30].

\section{Solar energy resources}

Nigeria has an average annual solar incident of about $1,831.06 \mathrm{kWh}$ with a total land area of $923,768 \mathrm{~km}^{2}$. Evaluation of the technical potential of solar energy in
Nigeria shows that a useful annual energy of $15 \times 10^{14} \mathrm{~kJ}$ can be obtained with $5 \%$ device efficiency. This translates to about 258.62 million barrels of oil corresponding to $4.2 \times 10^{5} \mathrm{GWh}$ of electricity production annually [31]. The country has an annual average sunshine of about $6.25 \mathrm{~h}$, ranging from $3.5 \mathrm{~h}$ at the coastal regions to $9.0 \mathrm{~h}$ at the north $[3,29]$. Similarly, the mean daily solar radiation is about $5.25 \mathrm{kWh} / \mathrm{m}^{2} /$ day, ranging from $3.5 \mathrm{~kW} / \mathrm{m}^{2} /$ day at coastal zones to $7.0 \mathrm{kWh} / \mathrm{m}^{2} /$ day at the north [32-34]. The solar radiation distribution is shown in Fig. 3 [35]. Based on the map, three different solar radiation zones can be defined viz: zones I, II and III with each zone having different radiation levels (whose respective values are indicated on the figure legend) that may be needed for a particular project selection and sizing [35]. Table 3 gives the irradiation levels for each zone as distributed among the 36 States of the federation. Zone I comprises all the states in the northeast geo-political zones; with high solar radiation incident on the horizontal surface; it has excellent and viable potential for largescale solar photovoltaic especially in the semi-arid region. Zone II consisting of the northwest and north-central belt of the country also has viable solar radiation that may be required for most solar projects. Low potential of annual global solar radiation exists in zone III (comprising all locations in the south zone including the coastal region), and can only be suitable for stand-alone PV systems. However, some states/locations in the southwest and southeast regions can readily support decentralized energy projects.

\section{Energy supply and consumption pattern}

The overall energy production and consumption in Nigeria from 1980 to 2011 are presented in Fig. 4. Fluctuations are observed in some years in the production and consumption capacity. These fluctuations can be attributed to several factors including population increase, unstable government policies, youth restiveness in regions of oil exploration and international market dynamics. However, the overall primary energy production decreased from $113.2 \mathrm{~m}$ toe in 1980 to $83.2 \mathrm{~m}$ toe in 1988 , followed by an increase from $102.5 \mathrm{~m}$ toe in 1990 to $156.1 \mathrm{~m}$ toe in 2011 [8, 9, 11]; between 1980 and 2008, the energy consumption increased almost steadily at an annual rate of $9.2 \%$ and was thereafter followed by a decrease of $5.4 \%$ in 2010 due to recorded vandalizations of oil and gas infrastructures by oil bunkers/militants. In 2011, there was an increase of $20.5 \%$ annual rate giving a value of $28.8 \mathrm{~m}$ toe.

Table 4 depicts the energy consumption by type from 1980 to 2011. Crude oil remains the major primary energy 
Fig. 3 Solar radiation map of Nigeria. Data source [44]

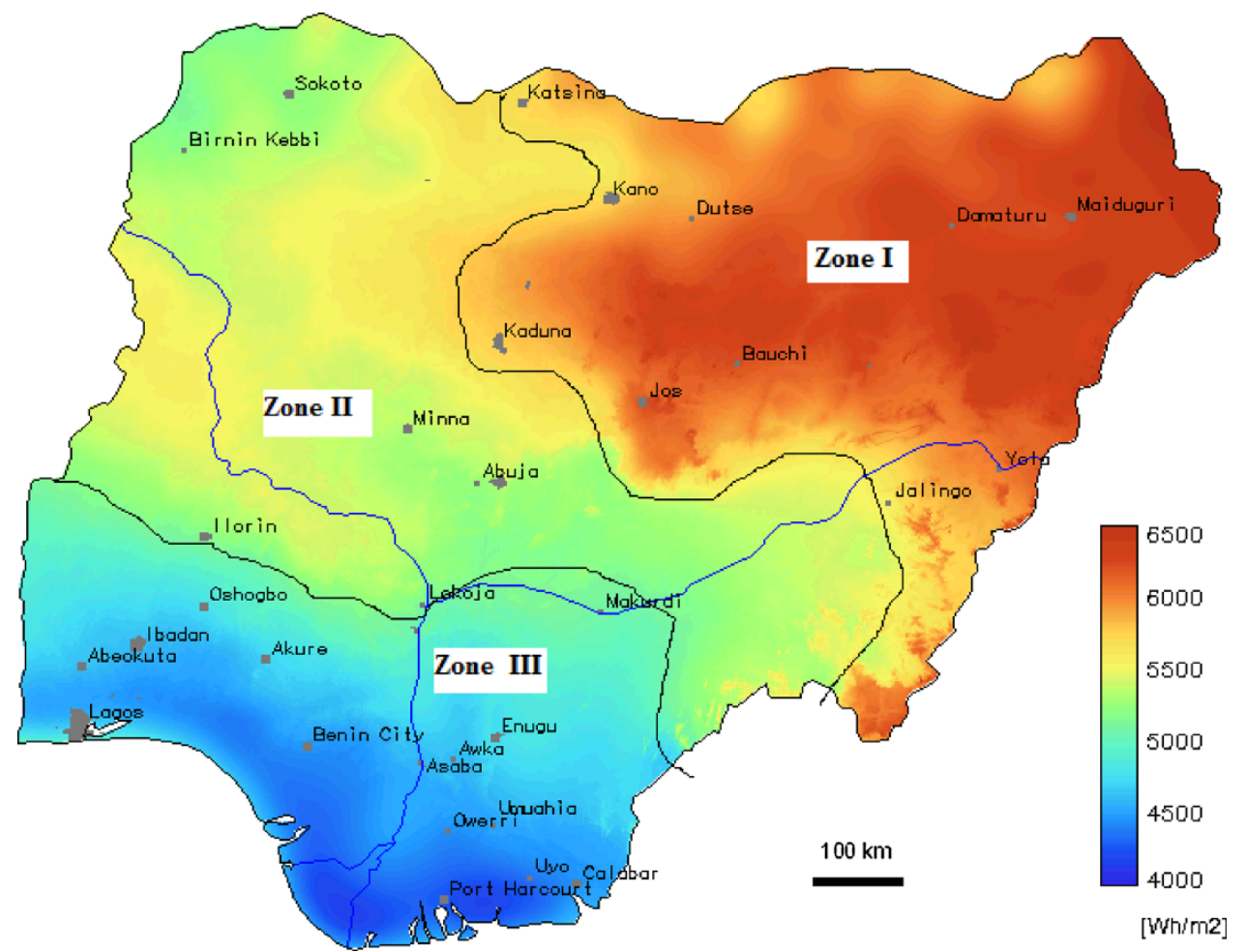

Table 3 Solar radiation zones (global horizontal irradiation) [47]

\begin{tabular}{|c|c|c|c|c|}
\hline Zones & $\begin{array}{l}\text { Annual average of } \\
\text { global solar radiation } \\
\left(\mathrm{kWh} / \mathrm{m}^{2} / \text { day }\right)\end{array}$ & $\begin{array}{l}\text { Sunshine } \\
\text { duration } \\
\text { (h/day) }\end{array}$ & $\begin{array}{l}\text { Annual average of } \\
\text { solar energy intensity } \\
\left(\mathrm{kWh} / \mathrm{m}^{2} / \text { year }\right)\end{array}$ & States \\
\hline Zone I & $5.7-6.5$ & 6.0 & 2,186 & $\begin{array}{l}\text { Borno, Yobe, Jigawa, Kano, Kaduna, Bauchi, Gombe, } \\
\text { Adamawa, Plateau and Katsina }\end{array}$ \\
\hline Zone II & $5.0-5.7$ & 5.5 & 2,006 & $\begin{array}{l}\text { Sokoto, Zamfara, Kebbi, Niger, FCT (Abuja), Nassarawa, } \\
\text { Taraba, Kwara, some section of Plateau, Benue, and Katsina }\end{array}$ \\
\hline Zone III & $<5.0$ & 5.0 & 1,822 & $\begin{array}{l}\text { Lagos, Oyo, Osun, Ekiti, Kogi, Benue, Rivers, Delta, Imo, } \\
\text { Anambra, Abia, Enugu, Edo, Ondo, Bayelsa, Akwa-Ibom, } \\
\text { Cross Rivers, Ebonyi }\end{array}$ \\
\hline
\end{tabular}

source in terms of production and consumption in the overall energy mix. However, the ratios of crude oil consumption in the energy mix (Table 4), dropped from $82.2 \%$ in 1982 to $69.8 \%$ in 1988 and later increased to $71.3 \%$ in 1990 . The ratio of consumption dipped from $66.6 \%$ in 1992 to $51.6 \%$ in 2011 [8, 9, 11]. The consumption of coal in the energy mix is comparatively small, declining from $1.6 \%$ in 1980 to a paltry quantity in 2011. This is due to over dependence on crude oil leading to neglect of coal exploitation in the country. The consumption of natural gas and renewable energy showed a steady increase. Natural gas increased from $8.9 \%$ in 1980 to $30.2 \%$ in 2011 while renewable energy consumption increased from 11.6 to $18.2 \%$ within the same period. The comparison of primary energy consumption in Nigeria and the world in 2011 is presented in Fig. 5 [11]. The share of primary energy production is also presented in Table 4.
Crude oil is still found to dominate the primary energy production mix. The production capacity reduced from $90.06 \%$ in 1980 to $78.4 \%$ in 2011 while coal decreased from 0.2 to $0.1 \%$. The share of crude oil production has in last decade declined at about $9.2 \%$ between 1994 and 2011 (Table 5), while renewable energy was found to decrease by $5.3 \%$.

\section{Sectoral energy consumption pattern}

The sectoral energy consumption in Nigeria for the year 2011 is presented in Fig. 6. The household (domestic) sector of the economy consumed the highest energy than other sectors. The energy consumption in the household increased from $25 \%$ in 1980 to $30 \%$ in the early 1990 s. Domestic energy consumption has increased rapidly since 1990 s to $38.16 \%$ in 2011 [36]. The second largest 


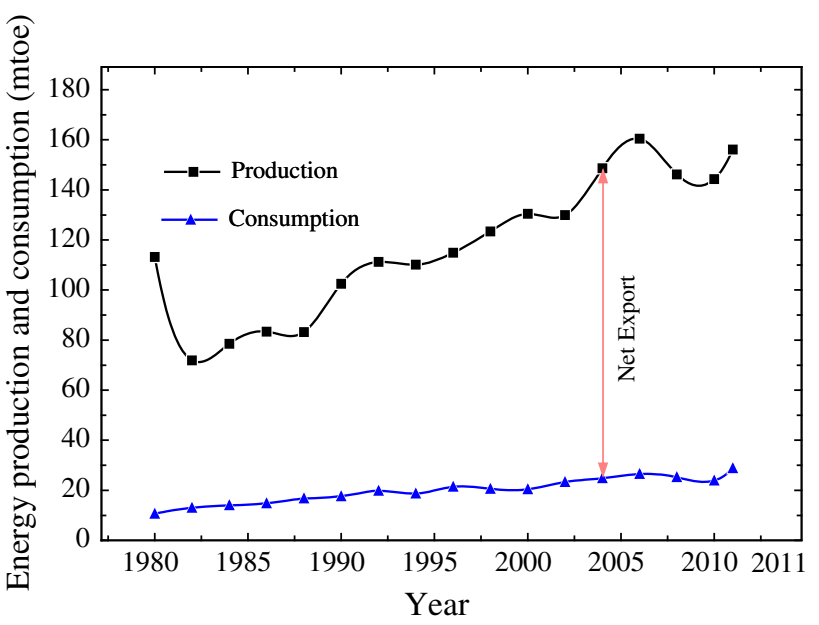

Fig. 4 Energy production and consumption in Nigeria (1980-2011). Data source $[8,11]$

Table 4 Energy consumption (between 1980 and 2011) in Nigeria (million toe) $[8,9,11]$

\begin{tabular}{llllll}
\hline Year & $\begin{array}{l}\text { Aggregate } \\
\text { consumption }\end{array}$ & \multicolumn{3}{l}{ As percentage of total energy consumption } \\
\cline { 3 - 6 } & & $\begin{array}{l}\text { Crude } \\
\text { oil }(\%)\end{array}$ & $\begin{array}{l}\text { Natural } \\
\text { gas }(\%)\end{array}$ & $\begin{array}{l}\text { Coal } \\
(\%)\end{array}$ & $\begin{array}{l}\text { Hydro, wind, } \\
\text { solar }(\%)\end{array}$ \\
\hline 1980 & 10.6 & 79.7 & 8.9 & 1.6 & 9.7 \\
1982 & 13.0 & 82.2 & 9.6 & 0.5 & 7.7 \\
1984 & 14.0 & 74.7 & 17.3 & 0.5 & 7.5 \\
1986 & 14.8 & 70.2 & 19.6 & 0.8 & 9.5 \\
1988 & 16.7 & 69.8 & 19.9 & 0.5 & 9.9 \\
1990 & 17.6 & 71.3 & 18.6 & 0.4 & 9.8 \\
1992 & 19.8 & 66.6 & 21.8 & 0.5 & 11.1 \\
1994 & 18.7 & 67.0 & 21.5 & 0.2 & 11.3 \\
1996 & 21.4 & 66.6 & 22.6 & 0.1 & 10.8 \\
1998 & 20.6 & 63.0 & 25.3 & 0.1 & 11.6 \\
2000 & 20.4 & 60.0 & 29.2 & 0.4 & 10.4 \\
2002 & 23.3 & 64.3 & 23.8 & 0.2 & 11.8 \\
2004 & 24.8 & 55.6 & 33.2 & 0.0 & 11.2 \\
2006 & 26.5 & 53.4 & 36.4 & 0.3 & 9.9 \\
2008 & 25.2 & 56.5 & 39.1 & 0.4 & 4.1 \\
2010 & 23.9 & 57.6 & 30.7 & 0.1 & 11.8 \\
2011 & 28.8 & 51.6 & 30.2 & 0.1 & 18.2 \\
\hline
\end{tabular}

consumer of energy in 2011 is the industrial sector which consumed about $28.91 \%$ of the overall energy. Its share was $6.3 \%$ in 1959 and rose to $15.7 \%$ after the oil boom in 1979. The transportation sector also witnessed a rapid growth in energy consumption as more roads were constructed in the early 1980s. In 2000, energy consumption in transportation was about $13.6 \%$ and further attained $27.62 \%$ in 2011 as shown in Fig. 2. The service sector has been stable since 2005 [36].
The electric power generating sector

The electric power generating sector in Nigeria is relatively small when compared with the teeming population and consequent energy consumption. The overall electricity production and consumption from 2000 to 2012 are presented in Fig. 7. The electricity production increased from 14.75 billion $\mathrm{kWh}$ in 2000 to 20.13 billion $\mathrm{kWh}$ in 2012 while consumption increased from 13.72 billion $\mathrm{kWh}$ in 2000 to 18.14 billion $\mathrm{kWh}$ in 2012 . The net consumption in 2011 was 18.14 billion $\mathrm{kWh}$ and slightly less than the generation in 2012; due to an agreement with Niger Republic under the West African Power Pool [37], appreciable portion of the electricity generated was exported to Niger Republic leaving back a short fall for the entire citizenry.

The electricity consumption per capita in Nigeria is also relatively low (Fig. 8), decreasing from $143 \mathrm{kWh}$ in 2005 to $106.63 \mathrm{kWh}$ in 2012 . The power-generating sector at the moment is faced with numerous problems in the generation, transmission and distribution units coupled with low plants performance due to aging infrastructure. The current installed generating capacity of Nigeria is small with average production of about 3,200 MW (Table 6) for a population of approximately 170 million people [37, 38]. To meet the country's power requirements, the current generation must be raised to more than twenty times the current value. Though the country has vast natural gas reserves that could be used to generate affordable and cheap power, its actual average production capacity has remained within 2,500-4,800 MW for the last decade. In a bid to meet the optimization plans through attaining the power generation gap of 26,561 MW by 2020 (Vision 20:2020), the Federal Government in October 2013 privatized the state-owned power firm to attract participations of foreign/private investments into the power sector [39].

\section{Challenges in energy expansion and sustainability}

Government emphasis on energy due to the numerous challenges has been on the supply of energy to the urban centers and industrial areas, thus causing an energy inequality within the country's energy demand profile. The current urban-centered energy strategy is inadequate, as instances of rural and sub-rural energy demand and distribution do not get to the center phase of the country's energy expansion plans [40]. The rural dwellers depend solely on wood and traditional biomass for their energy need which is worsening deforestation, general environmental pollution and a great risk to increasing climate change. Consequently, for sustainable economic growth sufficient production of energy and a dependable supply 

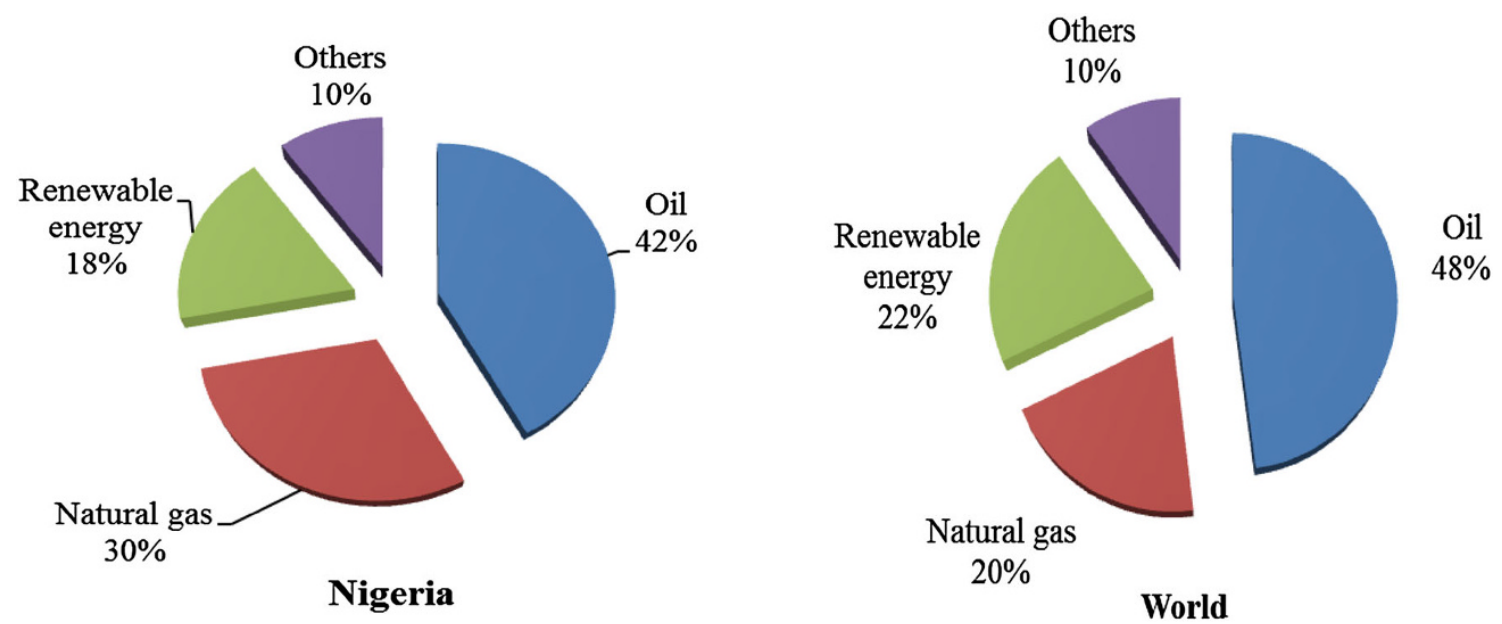

Fig. 5 Distribution of primary energy consumption in Nigeria and the world in 2011. Data source [11]

Table 5 Energy production (between 1980 and 2011) in Nigeria (million toe) $[8,9,11]$

\begin{tabular}{|c|c|c|c|c|c|}
\hline \multirow[t]{2}{*}{ Year } & \multirow{2}{*}{$\begin{array}{l}\text { Aggregate } \\
\text { production } \\
\text { (million } \\
\text { toe) }\end{array}$} & \multicolumn{4}{|c|}{ As percentage of total energy production } \\
\hline & & $\begin{array}{l}\text { Crude } \\
\text { oil }(\%)\end{array}$ & $\begin{array}{l}\text { Natural } \\
\text { gas }(\%)\end{array}$ & $\begin{array}{l}\text { Coal } \\
(\%)\end{array}$ & $\begin{array}{l}\text { Hydro, wind, } \\
\text { solar }(\%)\end{array}$ \\
\hline 1980 & 113.2 & 90.6 & 0.8 & 0.2 & 8.4 \\
\hline 1982 & 71.9 & 89.9 & 1.7 & 0.1 & 8.3 \\
\hline 1984 & 78.5 & 88.3 & 3.1 & 0.1 & 8.5 \\
\hline 1986 & 83.4 & 87.8 & 3.5 & 1.7 & 7.0 \\
\hline 1988 & 83.2 & 87.0 & 3.9 & 0.1 & 8.9 \\
\hline 1990 & 102.5 & 88.3 & 3.2 & 0.1 & 8.4 \\
\hline 1992 & 111.2 & 87.3 & 3.9 & 0.1 & 8.8 \\
\hline 1994 & 110.1 & 87.6 & 3.7 & 0.0 & 8.7 \\
\hline 1996 & 114.9 & 86.9 & 4.2 & 0.1 & 8.8 \\
\hline 1998 & 123.4 & 87.2 & 4.2 & 0.0 & 8.6 \\
\hline 2000 & 130.4 & 82.8 & 8.4 & 0.0 & 8.7 \\
\hline 2002 & 129.9 & 81.4 & 9.6 & 0.0 & 8.9 \\
\hline 2004 & 148.6 & 78.1 & 13.0 & 0.0 & 8.9 \\
\hline 2006 & 160.4 & 75.8 & 15.7 & 0.1 & 8.4 \\
\hline 2008 & 146.2 & 73.8 & 19.8 & 0.1 & 6.3 \\
\hline 2010 & 144.3 & 77.8 & 20.5 & 0.1 & 1.7 \\
\hline 2011 & 156.1 & 78.4 & 18.2 & 0.1 & 3.4 \\
\hline
\end{tabular}

system for all types of energy carriers will be necessary. This will ensure adequate availability of energy at both urban and rural areas. The challenges in energy development in Nigeria are thus summarized as follows.

Imbalance in energy demand and supply

Nigeria is a developing economy and gradually becoming more industrialized; however, much has to be done to catch up with the industrialized economies like China, Japan, etc.

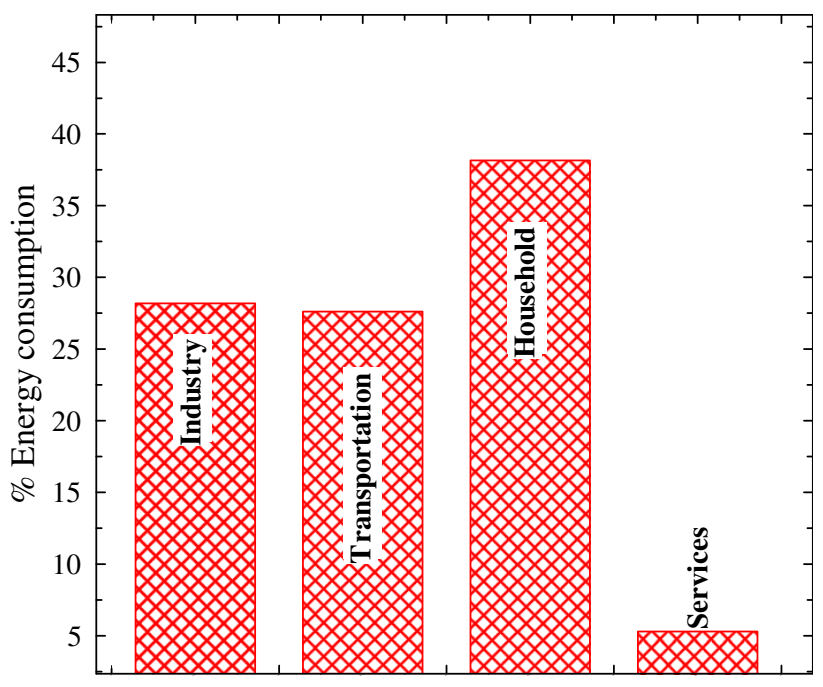

Fig. 6 Energy consumption by sector. Data source [7]

The energy consumption and GDP growth rates from 1980 to 2011 are presented in Fig. 9 [11, 12]. The energy consumption growth rate increased from $0.4 \%$ in 1980 to $1.10 \%$ in 2011 with an annual percentage change of about $1.6 \%$. The energy consumption growth rate was far less than those for the GDP with the exception in 1992 where the GDP growth rate declined to the minimum value of $0.43 \%$. This essentially shows an increase in energy demand owing to rapid population growth whose teeming energy demands are being met with meager supply. The electricity consumption per capita (kWh per person) was about $107 \mathrm{kWh}$ as at 2012 (Fig. 8); this is lower than the world average value of $2,659 \mathrm{kWh}$ and about $50,000 \%$ far from the leading country (Iceland) with 52,621 kWh [11]. This low electric energy consumption is a strong pointer that the total energy demand will surely increase with a 


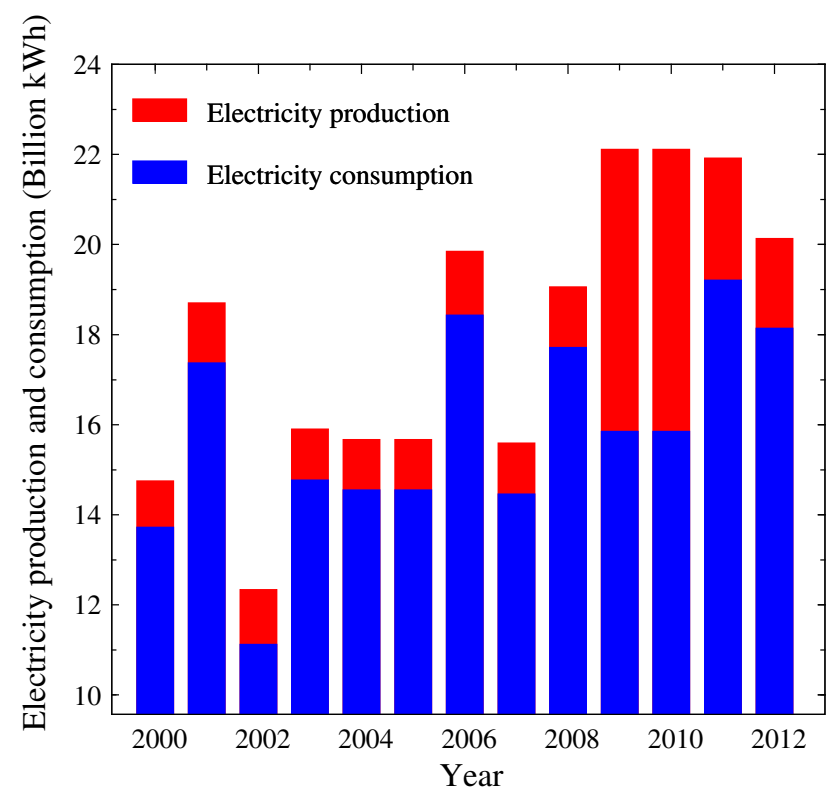

Fig. 7 Electricity production and consumption (2000-2012). Data source [33]

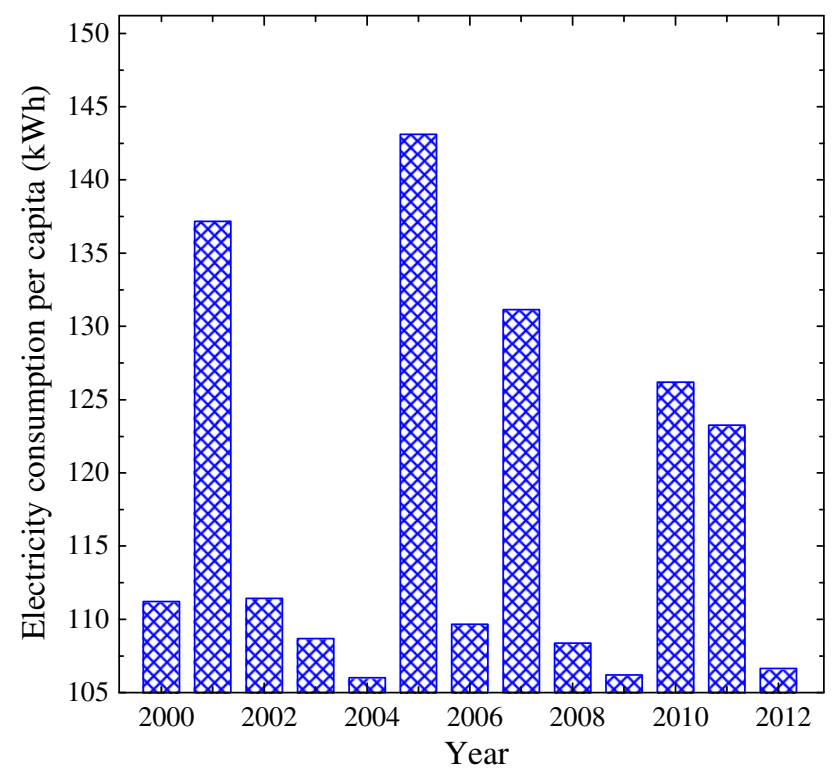

Fig. 8 Electricity consumption per capita (2000-2012). Data source [33]

corresponding improvement of the economy that will be needed to attain an increase in the living standards. Nigeria has enough energy resources to meet with the challenges of energy demand. However, the major reason for the shortage of domestic energy supply may not be unconnected to the overdependence on oil and non-diversification of energy resources in the country. Hence, for sustainable development, the energy demand and supply chain must be repositioned to attain a reasonable equilibrium.
Dependence on external energy resources for domestic consumption

The domestic production of oil and gas has continued to grow in the last two decades while production of coal has declined to almost zero by 2011. Large percentage of the oil produced in Nigeria is exported. Though Nigeria still remains the largest producer of crude oil in the continent, her refining capacity is very low. Figures 10 and 11 show the distribution of petroleum products to the Nigerian market and the percentage import of petroleum products (PPs) from 1980 to 2010 [11, 40, 41]. The PPs supply has been through domestic crude refining capacities and from external supply. The difference between these two dimensions of supply depends on the refining strength of the local refineries. The country has five state-owned domestic refineries with cumulative production capacity of 450,000 barrels of oil per day. The country still imports over $50 \%$ of PPs for her domestic consumption because of the inadequate refining capacity of these refineries. From 1980 to 2010 (Fig. 10) about 323.07 million tons of PPs was supplied to the domestic market out of which 206.19 million tons were supplied by local refineries and the rest (116.97 million tons) from external supply. The distribution system (Fig. 11) shows that $35.6 \%$ of PPs was imported in 1980, reflecting a decreasing trend of about $0.4 \%$ in 1991. The maximum imports of PPs were obtained in 2000 accounting for $73.7 \%$ and followed by a decline of about $39.8 \%$ in 2001 and 2002; about 34.76 million tons of PPs were imported from 2006 to 2010 and have remained relatively stable. A total of over 5,400 million USD was spent on subsidy for PPs between these years by the Nigerian National Petroleum Cooperation (NNPC). This situation is unhealthy for an economy that is characterized with a high level of unemployment and low technological capacity. The petroleum sector is also marked with structural problems ranging from inadequate human capacity and domestic technology needed to manage the oil dynamics especially in the downstream sector.

Furthermore, the following facts are required to move the sector forward: (1) a total restructuring of the hydrocarbon sector, (2) increase in PPs production, (3) rationalization of the decision-making mechanism by separating the different roles of NNPC, (4) privatization of the downstream activities of NNPC and (5) promotion of local contents. This becomes imperative because a robust sustainable domestic energy production will improve the standard of living, reduce poverty and boost industrialization.

Low energy efficiency

Indicators that affect energy efficiency (EE) include energy intensity (EI) and consumption elasticity coefficient 
Table 6 Grid electrical power energy sources in Nigeria [8, 19]

\begin{tabular}{|c|c|c|c|c|c|c|c|}
\hline Plant & $\begin{array}{l}\text { Plant } \\
\text { type }\end{array}$ & $\begin{array}{l}\text { Year of } \\
\text { installation }\end{array}$ & $\begin{array}{l}\text { Number of units } \\
\text { installed }\end{array}$ & $\begin{array}{l}\text { Installed } \\
\text { capacity } \\
(\mathrm{MW})\end{array}$ & $\begin{array}{l}\text { Current number } \\
\text { available }\end{array}$ & $\begin{array}{l}\text { Capacity } \\
\text { available } \\
\text { (MW) }\end{array}$ & $\begin{array}{l}\text { Operational } \\
\text { capacity } \\
\text { (MW) }\end{array}$ \\
\hline Kainji & Hydro & 1968 & 8 & 760 & 6 & 440 & 400 \\
\hline Jebba & Hydro & 1984 & 6 & 578.4 & 4 & 385.6 & 300 \\
\hline Shiroro & Hydro & 1990 & 4 & 600 & 4 & 600 & 300 \\
\hline Total & - & - & 18 & $1,938.4$ & 14 & $1,431.6$ & 1,000 \\
\hline Egbin & Thermal & 1968 & 6 & 1,320 & 4 & 880 & 600 \\
\hline Egbin AES & Thermal & 1984 & 9 & 270 & 9 & 270 & 220 \\
\hline Sapele (GT) & Thermal & 1981 & 10 & 1,020 & 1 & 90 & 65 \\
\hline Okpai & Thermal & 2007 & 3 & 480 & 3 & 480 & 400 \\
\hline Afam (I, II, II, IV) & Thermal & $(1965,1976,1978,1982)$ & 20 & 702 & 3 & 350 & 300 \\
\hline Delta (I, II, III, IV) & Thermal & $(1966,1975,1978,1990)$ & 18 & 840 & 12 & 540 & 330 \\
\hline Omoku & Thermal & 2007 & 6 & 150 & 4 & 100 & 80 \\
\hline Ajaokuta & Thermal & N/A & 2 & 110 & 2 & 100 & 80 \\
\hline Geregu & Thermal & 2007 & 3 & 414 & 3 & 414 & 414 \\
\hline Omotosho & Thermal & 2007 & 1 & 8 & 335 & 80 & 75 \\
\hline Olorunsogo & Thermal & 2007 & 8 & 335 & 2 & 80 & 35 \\
\hline Total & - & - & 93 & 5,976 & 44 & 3,384 & 2,589 \\
\hline
\end{tabular}

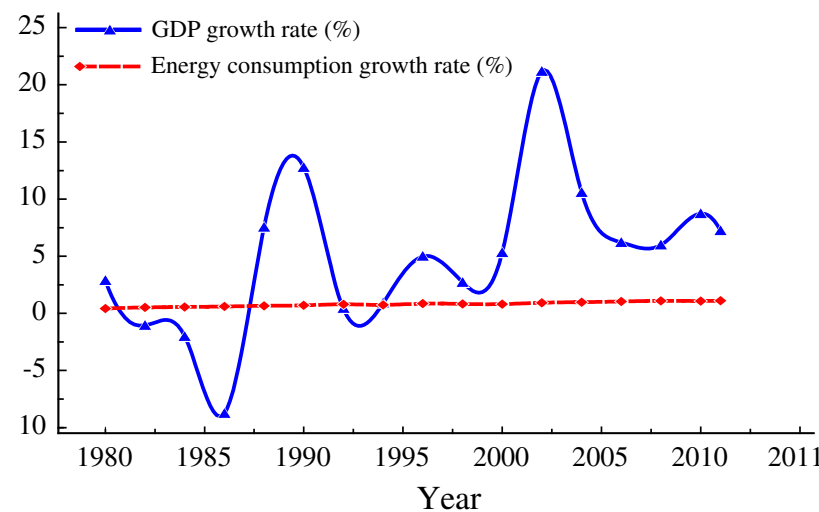

Fig. 9 Energy consumption and GDP growth rate in Nigeria (1980-2011). Data source [11, 12]

(ECEC). These indicators have a strong relationship with energy efficiency as they are related to economic growth and energy consumption. EI is the ratio of energy consumption to GDP output. It is the energy required to generate one dollar unit of gross output whereas ECEC is the rate at which energy is consumed to the GDP growth rate. Low value of EI in an economy shows a high level of efficiency. Equations (1) and (2) have been applied to data in [11] to obtain EI and ECEC from 1980 to 2011 as depicted in Figs. 12 and 13.

Energy intensity $(\mathrm{EI})=\frac{\text { Energy consumption }}{\text { GDP output }}$

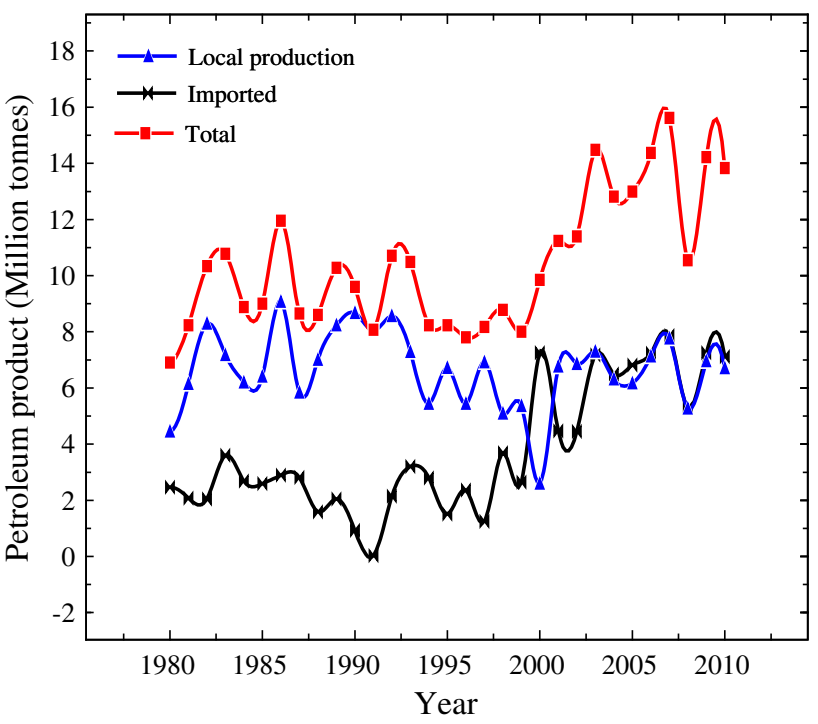

Fig. 10 Petroleum product supplies in Nigeria from (1980-2011). Data source [11, 37]

Consumption elasticity coefficient (ECEC)

$$
=\frac{\text { Energy consumption growth rate }}{\text { GDP growth rate }}
$$

Figures 12 and 13 show the change in overall EI and ECEC from year 1980 to 2011. The EI values decreased by $57.47 \%$ from 0.135 to 0.057 toe per US $\$ 1,000$ GDP (2005 price). In the same vein, EI from 1998 to 2011 dropped by $64.54,37.76,29.78,88.15$ and $85.76 \%$ for industry, 


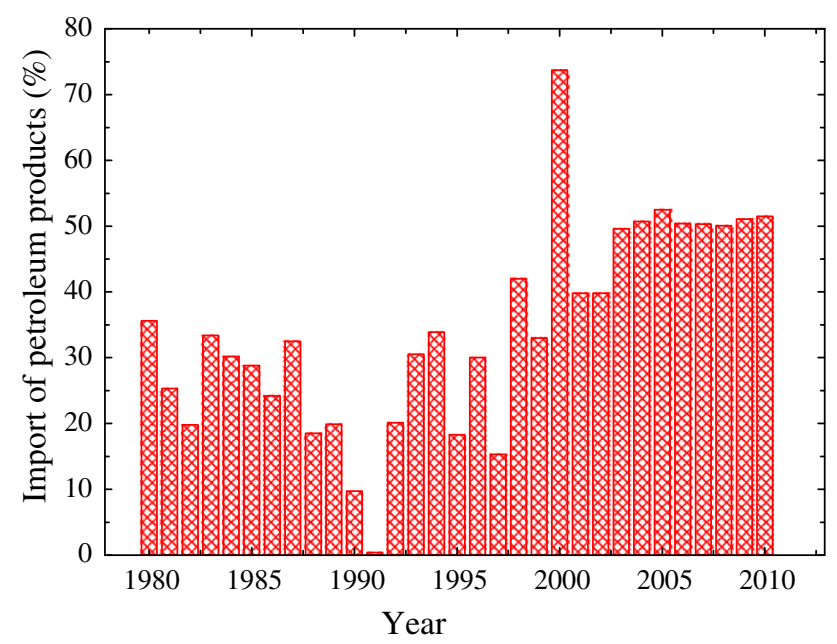

Fig. 11 Percentage of import of petroleum products (1980-2011). Data source $[11,37]$

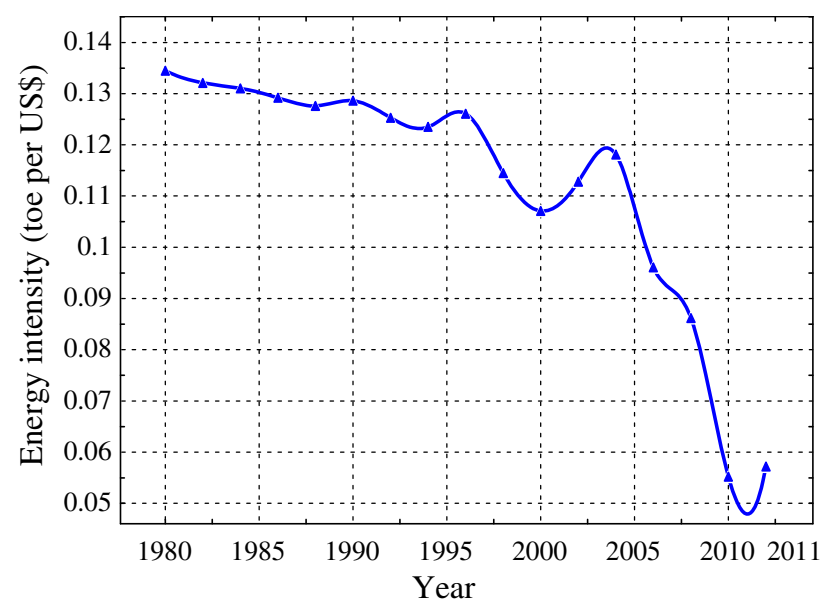

Fig. 12 Total energy intensity of Nigeria (1998-2011). Data source $[11,12]$

transportation, agriculture, commercial and residential sectors, respectively [11]. The decline in EI is a sign of efficient improvements. However, the improvements in the overall EE have been remarkably small. The sectoral EI are thus discussed:

\section{Agricultural sector}

The sectoral energy intensities in Nigeria from 1990 to 2011 are presented in Fig. 14. The EI for some sectors has proven to improve over the years. The EI of the agricultural sector decreased by $79.6 \%$ from 0.003 toe per US $\$ 1,000$ in 1990 to 0.001 toe per US\$1,000 in 1998 and its contribution to the total EI in these years was $2.7 \%$. From 2000 to 2004, the EI increased by $6.8 \%$ whereas between 2008 and 2011 the EI decreased from 0.004 to 0.002 toe per US\$1,000 GDP (2005 price). The intensity of energy

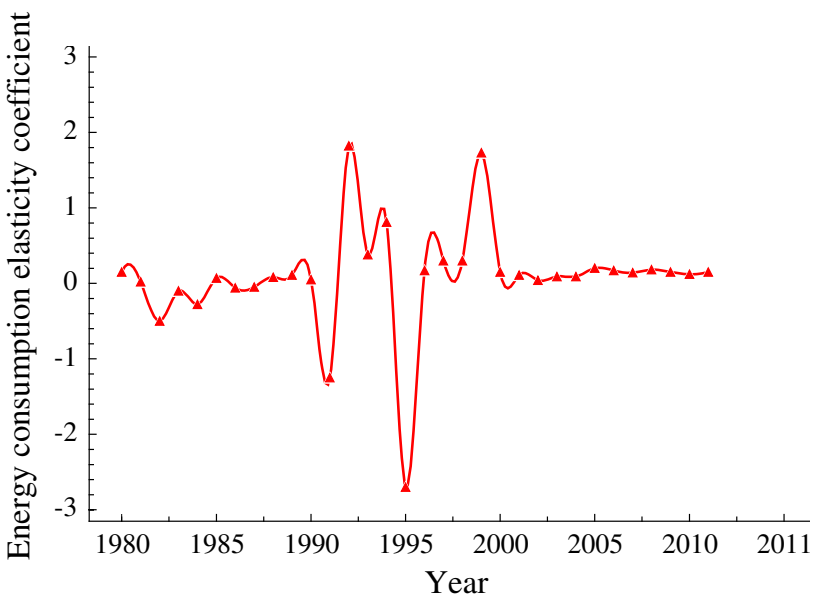

Fig. 13 Energy consumption elasticity coefficient (1980-2011). Data source [7]

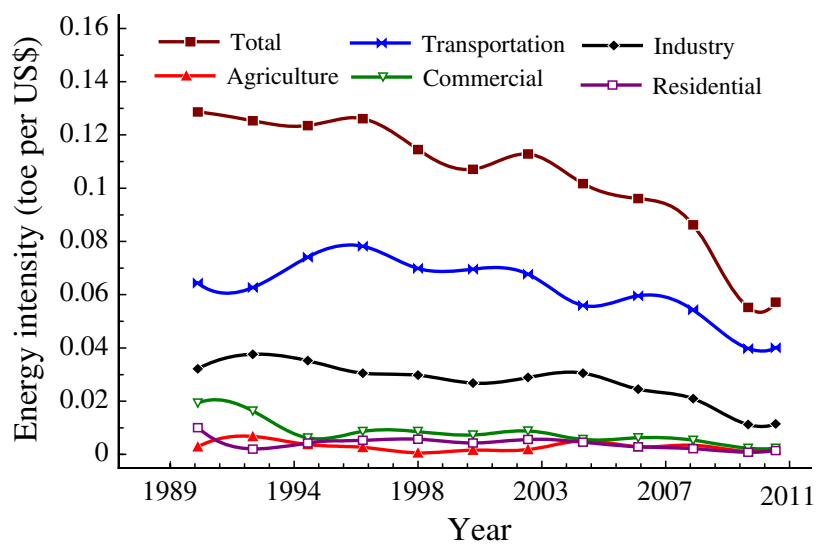

Fig. 14 Energy intensity by sectors (1990-2011). Data source [7, 11]

use in the agricultural sector was remarkably small between 1998 and 2002. The contribution of agriculture to the total EI within these years was $1.2 \%$, indicating low energy use. However, the energy use in this sector is historically low as most production stems from subsistence agriculture characterized by high human labor intensity, little or no irrigation (rain fed agriculture) and little or no mechanized farming.

\section{Industrial sector}

The industrial sector (Fig. 14) experienced an increase in EI from 1990 to 1994. The EI varies from 0.032 to 0.035 toe per US\$1,000 in 1990 and 1994, respectively, indicating an increase by $8.7 \%$ and contributing about $27.8 \%$ to the total EI in these years. Between 1996 and 2000, the EI steadily decreased from 0.031 to 0.027 toe per US $\$ 1,000$ in 1996 and 2000 giving a drop of $13.55 \%$ and a contribution to the total EI of about $25 \%$. Subsequently, between 2002 
and 2004 the EI increased by $5.4 \%$ and decreased significantly by $54.3 \%$ from 2006 to 2011 ; this may be due to changes in government fiscal policy on the industrial sector and some forms of efficiency measures. However, the primary driving force of the energy intensity of the industrial sector is the rapid growth of investment and also, increase in number of energy intensive industries like the steel manufacturing, cement and construction.

\section{Transportation sector}

The transportation sector comprising the road, air and water remained the principal consumer of energy in Nigeria (Fig. 14). The EI of the sector rose by $17.74 \%$ with increase from 0.064 toe per US $\$ 1,000$ in 1990 and reaching a value of 0.078 toe per US $\$ 1,000$ in 1996 . The contribution to the total EI from 1990 to 1996 was $55.47 \%$. The EI value decreased from 0.069 to 0.039 toe per US\$1,000 in 1998 and 2010 indicating a drop of $43.17 \%$ with a slight increase of $1.65 \%$ in 2011. The contribution of the transportation sector to the total EI from 1990 to 2011 was the highest and stood at $59.63 \%$.

\section{Residential/commercial sectors}

The EI of the residential sector decreased from 0.010 toe per US $\$ 1,000$ in 1990 to 0.001 toe per US $\$ 1,000$ in 2011 reflecting a drop by $90 \%$. The EI of the residential sector have been on the decrease over the studied periods indicating a little use of energy in the sector. The reason for the low EI in the sector is due to the epileptic power supply and non-availability of grid supply to the rural communities of the country where about $70 \%$ of the entire population reside. The contribution of the residential sector to the total EI from 1990 to 2011 was $3.99 \%$. The commercial sectors are also characterized with low EI values. The EI of the sector decreased from 0.019 toe per US $\$ 1,000$ in 1990 to 0.002 toe per US $\$ 1,000$ in 2011 having drop of $89.47 \%$. The contribution of the sector to the total EI between 1990 and 2011 was 7.84 and $3.85 \%$ above that of the residential sector. The sector witnessed an increase in EI by $28.1 \%$ between 1994 and 1996 followed by a $17.27 \%$ decrease between 2000 and 2002. The fluctuations in the performance may be attributed to the unstable economic policies. However, the commercial and the residential sectors have been characterized with low energy use which is an evidence of low energy use activities.

\section{The period 1980 to 2000}

The period from 1980 to 2000 was characterized by decrease in total EI and $\mathrm{CO}_{2}$ emissions per unit GDP as

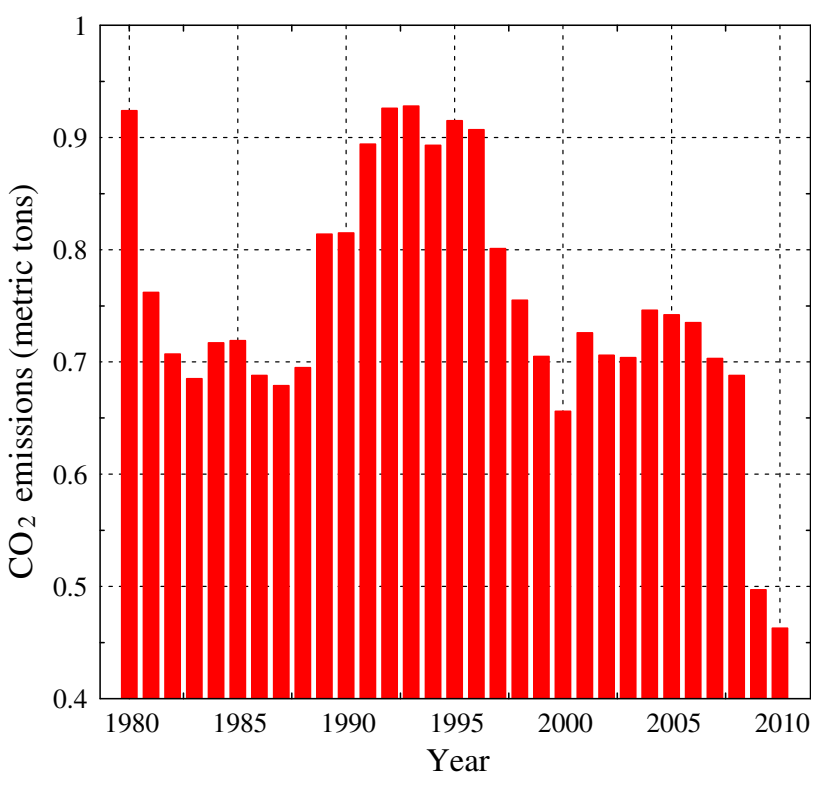

Fig. 15 Per capita $\mathrm{CO}_{2}$ emissions from the consumption of energy (1980-2010). Data source [41]

shown in Figs. 9 and 15. The overall $\mathrm{CO}_{2}$ emissions and per person $\mathrm{CO}_{2}$ emissions were also found to increase as the energy consumption increases. The average GDP growth rate was $2.45 \%$ while the energy consumption growth rate was $0.39 \%$. This was satisfactory for a sustainable development where the energy consumption growth rate was reasonably lower than the GDP growth rate. It was observed that the ECEC within this period was around 0.15 and from 1992 to 1995 the country's economy improved with a corresponding reduction in energy consumption leading to a negative ECEC (Fig. 13).

\section{The period 2001 to 2004}

The period from 2001 to 2004 witnessed an increase in energy consumption with a corresponding increase in $\mathrm{CO}_{2}$ emissions per capita. The ECEC at this period was 0.20 with a $12 \%$ increase in EI (Fig. 13). The GDP growth rate shown in Fig. 9 was $5.2 \%$ while the energy consumption growth rate was $0.98 \%$; this may be attributed to the increase in investment, the resuscitation and establishment of the cement industry, small steel industries, establishment of new gas turbine plants and the rapid growth witnessed in the telecommunication industries. For example, MTN a telecom company and the leading mobile phone provider in Nigeria had over 6,000 diesel generators installed for power supply in its base stations. The plants operate for $20 \mathrm{~h}$ a day, and the company spends about 5.5 million USD on diesel fuel yearly to keep the plants running [41, 42]. Other providers also exist to give a boom to the sector. It will also be deduced that the improvement of the economy from 1980 to 2000 and from 2001 to 2004 was marginal. 


\section{The period 2005 to 2011}

From 2005 to 2011, there was a decline in EI but the energy consumption growth rate was almost steady though declined in between years. The EI for the industrial sector (Fig. 14) was found to have dipped from 0.022 to 0.011 toe per US $\$ 1,000$ while the $\mathrm{CO}_{2}$ emissions per capita (Fig. 15) declined by $37.6 \%$ from 2005 to 2010 . The GDP and energy consumption growth rates were 2.11 and $0.06 \%$, respectively. This small sustainable improvement in energy efficiency obtained especially between 2005 and 2011 was attributed to policy measures and energy programs launched by the Energy Commission of Nigeria (ECN) in 2004 [43]. In addition, the low energy growth rate from 2005 to 2011 may be attributed to the decay in the performance of the industrial sector. The contribution of the industrial sector in real GDP declined from $3.59 \%$ in 2009 to $4.49 \%$ in 2010 while that of the transportation declined from $6.83 \%$ in 2009 to $6.79 \%$ in 2010. The drop in performance of the industrial sector was due to inadequate infrastructure especially energy, transport, high cost of funds, multiple taxation and small domestic patronage whereas for the transportation sector, the low trade-associated activities and the poor state of the highways decelerated the growth [44].

\section{Challenges of carbon pollution}

Crude oil and natural gas account for about 42 and $32 \%$ of the country's total energy consumption compared to 48 and $20 \%$ of the world average values (Fig. 5). Pollutant emissions in Nigeria are mostly from consumption of these energy sources and accounts for over $75 \%$ of $\mathrm{CO}_{2}$ emissions. The major sources of $\mathrm{CO}_{2}$ emissions are from coal and crude oil/petroleum consumption due to their respective carbon content. The total $\mathrm{CO}_{2}$ emission has increased steadily from 94 to 101 million metric tons between 1992 and 1996. Coal accounted for $2.8 \%$ of $\mathrm{CO}_{2}$ emissions while natural gas consumption, natural gas flaring and petroleum consumption accounted for 15.69, 62.94 and $33.61 \%$ of $\mathrm{CO}_{2}$ emissions, respectively [11]. The total $\mathrm{CO}_{2}$ emissions from gas flaring dropped from $62.94 \%$ in 1996 to $47.23 \%$ in 2011. This drop was due to government policy directing all oil-producing companies to shut in oil fields where the gas production and flaring were considerably more than the crude oil produced. This culminated into a reduction in the volume of gas flared from 2.5 to $1.5 \mathrm{bcf} / \mathrm{d}$ in 2010 [45]. With the country trailing the path of industrialization, there is large potential for the total $\mathrm{CO}_{2}$ to increase as the energy consumption rises to compensate for the growing and economy. The comparison of per capita $\mathrm{CO}_{2}$ emission for some selected African countries in 2009 is presented in Fig. 16. The world $\mathrm{CO}_{2}$ emissions per capita

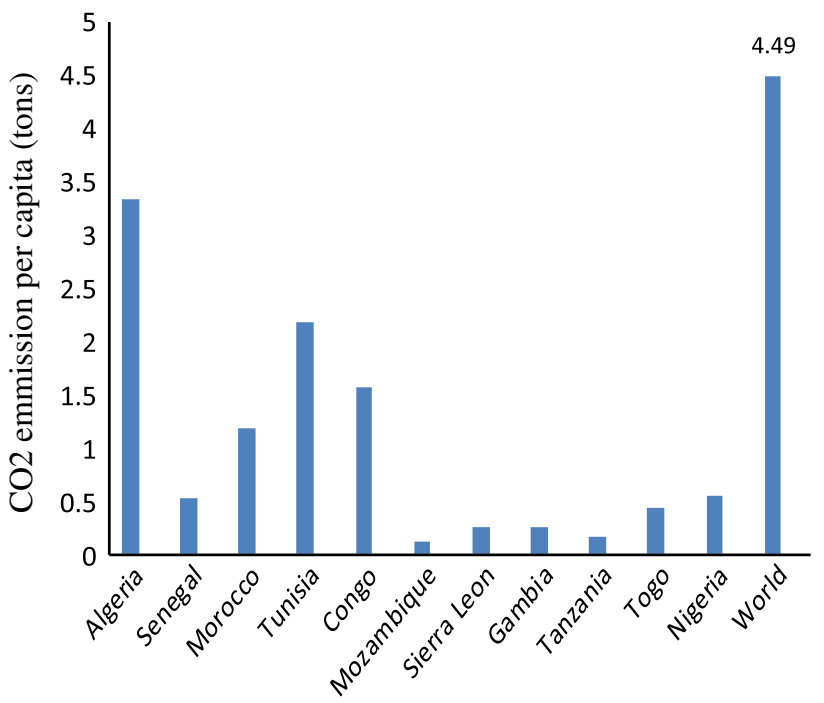

Fig. 16 Comparison of $\mathrm{CO}_{2}$ emission per capita of some African countries in 2009. Data source [42]

were estimated at 4.49 tons in 2009 [45], with Nigeria having a share of 0.52 tons; Algeria and Tunisia emitted the highest value of 3.33 and 2.18 tons, respectively. In 2011, Nigeria contributed about $0.32 \%$ to the world $\mathrm{CO}_{2}$ emissions recording a dip of about $0.002 \%$ from 2009 [46]. Furthermore, Africa has the potential of $\mathrm{CO}_{2}$ increase and based solely on the ground that the majority of countries in Africa are growing almost simultaneously and struggling for economic independence from the large economies. This growth will inevitably be complimented with an increase in energy consumption and the consequent increase in $\mathrm{CO}_{2}$ emission.

\section{Energy policies in Nigeria}

In 2004, the National Energy Policy provided a framework for optimal use of the country's energy resources (renewable and conventional) for sustainable development [43]. This includes to [43]:

- Ensure adequate growth of the country's energy resources, with varying energy resource options, for the implementation of national energy security, efficient energy supply system and a balanced energy mix,

- Ensure increased contribution of energy productive activities to federal income,

- Guarantee adequate, reliable and sustainable energy supply at competitive costs and in an environmentally sustained manner, to the different segments of the national economy for substantial development,

- Ensure an efficient and cost-effective utilization form of energy resources, 
- Expedite the process of acquisition and dissemination of technology and managerial competence in the sector and strengthen local content for adequate stability and self-sufficiency,

- Promote increased investments and expansion of the energy sector industries with significant private sector participation,

- Develop a comprehensive, integrated and well-defined plan for the sector and initiate successful developmental programs,

- Promote international cooperation in energy marketing and projects development in both the African continent and the entire world,

- Manage the nation's abundant energy resources to promote international cooperation.

Sustainable energy development strategies

One of the major strategies to meet energy demand is through the adoption of energy-efficient appliances. ECN/ UNDP through a project has completed energy efficiency and conservation plans to reduce energy consumption at the residential sector by the replacement of incandescent bulbs with energy-saving bulbs [compact fluorescent lamps $(\mathrm{CFL})]$. The commission has recognized the fact that lighting alone takes more than $18 \%$ of the total power consumed in the residential sector compared to about $8-11 \%$ in the advanced countries [47]. It is projected that Nigeria needs about 50 million CFL's to replace the incandescent lamps in the residential sector; with this replacement, a saving of approximately 1,500 MW of electricity can be achieved. Other efficient master plan includes, the phasing out of backward generating capacity having low efficiency and rather investing in smart grid, enhancing electrical equipment through technological innovation for improved energy efficiency, introducing a national building codes, establishing federal efficiency standards to reduce electricity consumption, ensure appliances labeling and certification and energy conservation and management in industries.

In addition, the following sustainable strategies were pronounced according to the Renewable Energy Master Plan (REMP) [30] viz: (1) the need to move from a fossil economy to one driven by growing share of renewable energy and (2) harnessing renewable energy resources in a manner and at prices that will support the implementation of equitable and sustainable development. In this framework, the projected energy demands in the sectors of the economy are presented in Table 7 based on $7 \%$ growth rate. To meet with this demand, the target is to get solar contribution of 5, 75, and $500 \mathrm{MW}$ to the energy mix structure in 2012, 2015 and 2025, respectively, while wind
Table 7 Projected sectoral energy demand in Nigeria based on $7 \%$ growth rate [19]

\begin{tabular}{lrrrrr}
\hline Sector & 2010 & 2015 & 2020 & 2025 & 2030 \\
\hline Industry (\%) & 28.92 & 37.01 & 40.75 & 14.69 & 48.78 \\
Transport (\%) & 27.62 & 24.56 & 22.92 & 22.27 & 21.62 \\
Household (\%) & 38.16 & 33.05 & 30.62 & 27.27 & 24.12 \\
Service (\%) & 5.30 & 5.39 & 5.72 & 5.78 & 5.49 \\
\hline
\end{tabular}

Table 8 Targets for renewable power generation (MW) in Nigeria [19]

\begin{tabular}{|c|c|c|c|}
\hline Resources & $\begin{array}{l}\text { Short term } \\
2008\end{array}$ & $\begin{array}{l}\text { Medium term } \\
2015\end{array}$ & $\begin{array}{l}\text { Long term } \\
2030\end{array}$ \\
\hline Hydro (large) & 11,259 & 15,930 & 48,000 \\
\hline Hydro (small) & 3,500 & 7,430 & 11,900 \\
\hline Solar PV & 5 & 120 & 500 \\
\hline Solar thermal & - & 1 & 5 \\
\hline Biomass & - & 100 & 800 \\
\hline Nuclear & - & 1,000 & 4,000 \\
\hline Wind & 1 & 30 & 40 \\
\hline All renewable & 14,765 & 24,611 & 65,245 \\
\hline $\begin{array}{l}\text { All energy } \\
\text { resources }\end{array}$ & 17,000 & 30,000 & 190,000 \\
\hline
\end{tabular}

power contribution is set at 1, 19 and $38 \mathrm{MW}$ for same years for short term, medium term and long term in both cases [19].

Patterns of energy expansion strategies

The government expansion strategy in the energy sector includes the integration of energy resources that are nonfossil into the energy mix structure. Renewable energy is expected to contribute about 14, 23 and $36 \%$ for short, medium and long term of the overall energy and electricity supply in Nigeria by 2030. The targets for renewable energy production are presented in Table 8. Furthermore, wind energy resources in the short term will require an increase of more than a hundred percentage to produce $30 \mathrm{MW}$ in 2015 and $40 \mathrm{MW}$ in 2030. Some wind power projects are being in existence and operational (though on a small scale). Solar PV installations are on the increase and about $1 \mathrm{MW}$ total dispersed installations are going on country wide for low energy applications such as water pumping, street lighting, vaccine refrigerators and community lighting [48].

\section{Conclusions}

Nigeria is the largest and most populated country in Africa; a fast-developing nation and a major player among oil- 
producing countries in the world. The country is still lacking in terms of providing sufficient energy to run her economy despite the high increase in demand. The energy consumption has increased in the last three decades. The consumption rate increased by $3.6 \%$ in 2011 over that in 2010 , giving a total energy utilization of about 4.4 quadrillion with traditional biomass while wastes contribute about $82 \%$ of the overall energy consumption. The estimated conventional energy reserve in 2011 stood at 2.7 billion tons for coal, 37.2 billion barrels for crude oil and 5.1 trillion cubic meters for natural gas. The country is also naturally endowed with vast deposition of renewable energy resources.

Furthermore, most of the challenges faced by the energy sector were found to exist from imbalance in energy demand and supply, dependence on external energy resources for domestic consumption, low energy efficiency and environmental pollution. Hence, in a bid to address these problems, the government has structured strategies which include reduction of energy consumption in the residential and industrial sector through an effective energy conservation and management system, with the integration of renewable and clean energy resources into the total energy mix. Under this new policy, the energy demand and supply is expected to be implemented in a sustainable way to achieve the needed balance between economic development, social development and eco-friendly protection.

Acknowledgments Authors appreciate the Library staff of Central Bank of Nigeria, Calabar for their cooperation in making it possible to access the data used for this study.

Conflict of interest The authors declare that there are no conflicts of interests regarding the publication of this article.

Authors' contributions FIA collected data and drafted the manuscript. BNN, OSO carried out a thorough review and evaluation of the data. FIA and SAO supervised the study and approved the first draft. The authors all read and approved the final manuscript.

Open Access This article is distributed under the terms of the Creative Commons Attribution License which permits any use, distribution, and reproduction in any medium, provided the original author(s) and the source are credited.

\section{References}

1. Ajayi, O.O., Ajanaku, K.O.: Nigeria's energy challenge and power development: the way forward. Bull. Sci. Assoc. Niger. 28, 1-3 (2007)

2. Kalu, U., Tomasz, A.: Sustainable energy development: the key to a stable Nigeria. Sustainability 2, 1558-1570 (2010). doi:10. 3390/su2061558

3. Ohunakin, O.S.: Energy utilization and renewable energy sources in Nigeria. J. Eng. Appl. Sci. 5, 171-177 (2010)

4. Suleiman, S.: Energy consumption and economic growth: causality relationship for Nigeria. OPEC Energy Rev. 34(1), 15-24 (2010)
5. Nigeria-Economy (2005). http://www.mogabay.com/reference/ country_studies/nigeria/Economy/.htlm. Accessed 04 Jan 2013

6. Chendo, M.A.: Non-conventional energy sources: development in Nigeria. Niger. J. Renew. Energy 9(1), 91-102 (2007)

7. Central bank of statistical bulletin 1 (4) (2012) http://www.cen bank.org/document/statbulletin. Accessed 04 Jan 2013

8. Central Bank of Nigeria (CBN) Annual report and statement of accounts (2011). http://www.cenbank.org/out/2012/publications/ report/rsd/arp/2011 Accessed 05 Feb. 2013

9. National Bureau of Statistics (NBS) Annual abstract of statistic (2011). http://www.nigerianstat.gov.ng/. Accessed 05 Feb 2013

10. Obadote, DJ: Energy crisis in Nigeria: technical issues and solutions. Power sector conference (2009)

11. CIA World Factbook, Nigeria (2012). https://www.cia.gov/ library/publications/the-world-factbook/geos/ni.html. Accessed $05 \mathrm{Feb} 2013$

12. US Energy information Administration (2010). Country analysis briefs: Nigeria. http://www.eia.gov/countries/country-data.cfm. Accessed 15 June 2013

13. Nigeria energy data, statistics and analysis-oil, gas, electricity and coal (2012). http://www.fayzeh.com/Nigeria.htm. Accessed $11 \mathrm{Feb} 2013$

14. Coal and lignite, Online Nigeria. http://www.onlinenigeria.com/ geology/blurb. Accessed 09 Oct 2013

15. National Bureau of Statistics (NBS) (2007). National Core Welfare Indicator Questionnaire (CWIQ) Survey. National Bureau of Statistics (NBS), Abuja, p 2, Summary Sheet

16. M2M Workshop-Nigeria: Nigeria's Country report on coal mine methane recovery and use, presented at the methane to markets regional workshop, December 2, 2005, Beijing, China

17. Coal exploration and power generating opportunities in Nigeria. The ministry of mines and steel development (2010). http:// mmsd.gov.ng/Downloads/Coal.pdf. Accessed 12 July 2013

18. Nigeria to build nuclear power plant (2009). http://www.niger iancurocity.com/2009/12/nigeria-to-build-power-plant-htlm. Accessed 09 Oct 2013

19. Energy commission of Nigeria. ECN annual report, Abuja (2011)

20. Iloeje, OC: Renewable energy development in Nigeria: status and prospects. In: Proceedings of a National workshop on energizing rural transformation in Nigeria: scaling up electricity access and renewable energy (2002)

21. Country-hydropower (2010). http://www.Hydroelectric-energy. blogspot.com/2010/06/countries-with-most-hydro-electric.htm. Accessed 04 Sept 2012

22. Ohunakin, O.S., Oyewola, O.M., Adaramola, M.S.: Economic analysis of wind energy conversion systems using levelized cost of electricity and present value cost methods in Nigeria. Int. J. Energy Environ. Eng. 4, 2 (2013)

23. Oyedepo, S.O., Adaramola, M.S., Paul, S.S.: Analysis of wind speed data and wind energy potential in three selected locations in south-east Nigeria. Int. J. Energy Environ. Eng. 3, 7 (2012)

24. Idris, N.A., Lamin, H.S., Ladan, M.J., Yusuf, B.H.: Nigeria's wind energy potentials: the path to a diversified electricity generation-mix. Int. J. Mod. Eng. Res. 2(4), 2434-2437 (2012)

25. Ohunakin, O.S.: Wind resources in North-East geopolitical zone, Nigeria: assessment of the monthly and seasonal characteristics. Renew. Sustain. Energy Rev. 15, 1977-1987 (2011)

26. Ohunakin, O.S.: Assessment of wind energy resources for electricity generation using WECS in North-Central region, Nigeria. Renew. Sustain. Energy Rev. 15, 1968-1976 (2011)

27. Ohunakin, O.S., Adaramola, M.S., Oyewola, O.M.: Wind energy evaluation for electricity generation using WECS in seven selected locations in Nigeria. Appl. Energy 88, 3197-3206 (2011)

28. Adaramola, M.S., Oyewola, O.M., Ohunakin, O.O., Dinrifo, R.R.: Techno-economic evaluation of wind energy in southwest Nigeria. Front. Energy 6(4), 366-378 (2012) 
29. Akin, I.: Nigeria's dual energy problems: policy issues and challenges inter. Assoc. Energy Econ. 2, 17-18 (2008)

30. Energy Commission of Nigeria and United Nations Development Programme (ECN-UNDP). Renewable Energy Master Plan (REMP): final draft report (2005)

31. Ilenikhena, PA, Ezemonye, LN: Solar energy applications in Nigeria.WEC Montreal 135 (2010). http://www.worldenergy.org/ documents/congress/135.pdf. Accessed 08 Sept 2013

32. Sambo, AS: Renewable Energy Development in Nigeria. In: Energy commission of Nigeria paper presented at the World's future council and strategy workshop on renewable energy, Accra, Ghana, June, 2010

33. Okafor, C., Joe-Uzuegbu, E.N.: Challenges to development of renewable Energy for electric power sector in Nigeria. Int. J. Acad. Res. 2(2), 211-220 (2010)

34. Oloketuyi, S.I., Oyewola, O.M., Odesola, I.F.: Determination of optimum tilt angles for solar collectors in low-latitude tropical region. Int. J. Energy Environ. Eng 4, 29 (2013)

35. Ohunakin, O.S., Adaramola, M.S., Oyewola, O.M., Fagbenle, R.O.: Solar energy applications and development in Nigeria: drivers and barriers. Renew. Sustain. Energy Rev. 32, 294-301 (2014)

36. Central Bank of Nigeria (CBN) Annual report and statement of accounts (2012)

37. Electricity production and consumption in Nigeria (2012). http:// www.indexmundi.com. Acessed 08 Sept 2013

38. Abam, F.I., Ugot, I.U., Igbong, D.I.: Thermodynamic assessment of grid-based gas turbine power plants in Nigeria. J. Emerg. Trends Eng. Appl. Sci. 6, 1026-1033 (2011)
39. Nigeria selling state power firm. http://www.reuters.com/article/ 2013/09/30. Accessed 04 Oct 2013

40. Oyedepo, S.O.: Energy and sustainable development in Nigeria: the way forward. Energy Sustain. Soc. 2(15), 2-17 (2012)

41. Dayo, FB: Clean energy investment in Nigeria. The domestic content. A country case study completed for IISD's clean energy investment project 2008

42. Uduma, K., Arciszewski, T.: Sustainable energy development: the key to a stable Nigeria. Sustainability 2, 1558-1570 (2010)

43. National Energy Policy. Energy Commission of Nigeria. http:// www.osgf.gov.ng/payload?id=ff0bfcf6-2376-4a37-9fe651b73e550fbc. Accessed 26 Oct 2013

44. Annual-performance-of the Nigerian economy (2010). http:// www.dostoc.com/docs/132192969. Acessed 04 Oct 2013

45. International energy statistics (2010). http://www.toto.eia.doe. gov/cfapps/ipdbproject. Accessed 23 Oct 2013

46. Carbon dioxide (CO2) emissions per capita in Nigeria. http://www. theglobaleconomy.com/Nigeria/indicator. Accessed 18 Oct 2013

47. Demand side management and efficient lighting initiatives in Nigeria. Paper presented at the WEC Africa Workshop on Energy Efficiency Addis Ababa, Ethiopia 29-30 June 2009

48. Huld, T, Śúri, M, Dunlop, E, Albuisson, M, Wald, L: Integration of HelioClim-1 database into PVGIS to estimate solar electricity potential in Africa. In: Proceedings from 20th European photovoltaic solar energy conference and exhibition Barcelona, Spain. 6-10 June 2005 